\title{
REKOMENDASI PENYEDIAAN RTH PUBLIK AKTIF DI KECAMATAN KEPANJEN BERDASARKAN PERSEPSI MASYARAKAT
}

\author{
Nisrina F Shakia*, Wisnu Sasongko, Deni Agus Setyono \\ Jurusan Perencanaan Wilayah dan Kota Fakultas Teknik Universitas Brawijaya \\ Jalan Mayjen Haryono 167 Malang 65145 - Telp (0341)567886 \\ *e-mail: nisrinashakia@gmail.com
}

\begin{abstract}
ABSTRAK
RTH publik aktif merupakan RTH yang digunakan oleh pengunjung untuk melakukan aktivitas tertentu. Aktivitas yang sering dilakukan oleh pengunjung di RTH publik aktif antara lain berjalan, bersepeda, berlari, berolahraga, atau bermain bagi anak-anak. Perencanaan RTH publik aktif telah menjadi sebuah prioritas pada setiap wilayah karena RTH publik aktif dimanfaatkan sebagai tempat bagi masyarakat untuk berinteraksi dan melakukan aktivitas secara individu ataupun berkelompok. Kecamatan Kepanjen merupakan satu dari tiga puluh tiga kecamatan di Kabupaten Malang yang hanya memiliki lima RTH publik aktif dengan total luas sekitar 3,00 ha. Maka dari itu, Kecamatan Kepanjen belum dapat memenuhi persentase minimal penyediaan RTH publik aktif pada kawasan perkotaan, sehingga RTH publik aktif tersebut belum dapat melayani kebutuhan masyarakat secara keseluruhan. Tujuan dari penelitian ini adalah untuk merumuskan rekomendasi penyediaan RTH publik aktif di Kecamatan Kepanjen berdasar persepsi masyarakat. Teknik analisis yang digunakan dalam penelitian ini adalah Analisis Hierarki Proses (AHP). Hasil analisis kebutuhan RTH publik aktif mengidentifikasi bahwa Kecamatan Kepanjen hanya memiliki dua desa yang telah memenuhi persentase minimal penyediaan RTH publik aktif, yaitu Desa Ngadilangkung dan Desa Kedungpedaringan. Hasil kuesioner menunjukkan bahwa masyarakat Kecamatan Kepanjen memilih faktor kenyamanan sebagai faktor utama yang harus dipertimbangkan dalam penyediaan RTH publik aktif. Fasilitas yang penting untuk menunjang faktor kenyamanan berupa fasilitas tempat duduk dan fasilitas kebersihan. Hasil analisis AHP juga menunjukkan bahwa kenyamanan merupakan faktor yang paling berpengaruh dalam penentuan lokasi penyediaan RTH publik aktif di Kecamatan Kepanjen. Kenyamanan mencakup tentang tingkat kepentingan penyediaan fasilitas yang menunjang keamanan, kebersihan, dan ketersediaan tempat duduk pada RTH publik aktif. Berdasar hasil dari kedua analisis tersebut, selanjutnya disusun rekomendasi penyediaan RTH publik aktif di Kecamatan Kepanjen, yaitu perlu adanya penyediaan fasilitas yang dapat menunjang kenyamanan masyarakat ketika berkunjung ke RTH publik aktif. Fasilitas tersebut dapat berupa tempat duduk di dekat ruang bermain anak, sehingga pengunjung dapat menemani anak mereka bermain sembari bersantai.
\end{abstract}

Kata Kunci : Ruang-Terbuka-Hijau, RTH-Publik-Aktif, Analisis-Hierarki-Proses, Kecamatan-Kepanjen

\section{ABSTRACT}

Active public green open space is used to carry out certain activities include walking, cycling, running, exercising, or playing for children. Planning for active public green open space has become a priority in each region because public green open space is actively used as a place for people to interact and carry out activities individually or in groups. Kepanjen District is one of thirty three districts in Malang Regency that only has five active public green open spaces with a total area of 3,00 ha. However, this district still can't be able to achieve the minimum percentage of active public green open space, so that the active public green space has not been able to serve the needs of the community. This study aims to suggest recommendations for the provision of active public green open spaces in Kepanjen District based on community perceptions. This study uses AHP. The results of the active public green open space needs analysis identify that Kepanjen District only has two villages. It has achieved the minimum percentage of active public green open space. That two villages are Ngadilangkung Village and Kedungpedaringan Village. The results of the questionnaire shows that Kepanjen District's people choose comfort as the main factor to determine the location of active public green open space. Facilities that are important to support the comfort factor are seating and cleaning facilities. The results of AHP analysis also shows that comfort is the main factor to determine the location of active public green open space in Kepanjen District. Comfort includes the level of importance of providing facilities that support security, cleanliness, and availability of seats in active public green open space. Based on the results of that two analyzes, recommendation for providing active public green open space in Kepanjen District is provide facilities that comfort the community when they are visiting active public green open space. These facilities can be in form of seats near the children's playground, so the visitors can accompany their children to play while they are relaxing.

Keywords: Green-Open-Space, Active-Public-Green-Open-Space, Analytic-Hierarchy-Process, KepanjenDistrict. 


\section{PENDAHULUAN}

Peraturan Menteri Pekerjaan Umum Nomor 5 Tahun 2008 tentang Pedoman Penyediaan dan Pemanfaatan Ruang Terbuka Hijau di Kawasan Perkotaan menyebutkan bahwa Ruang Terbuka Hijau (RTH) adalah area memanjang/jalur dan atau mengelompok, yang penggunaannya lebih bersifat terbuka, tempat tumbuh tanaman, baik yang tumbuh tanaman secara alamiah maupun yang sengaja ditanam. Perencanaan Ruang Terbuka Hijau (RTH) bertujuan untuk menjaga ketersediaan lahan sebagai kawasan resapan air, menjaga keseimbangan lingkungan alam dan lingkungan buatan, dan meningkatkan kualitas lingkungan perkotaan yang sehat, indah, bersih, dan nyaman. RTH terdiri atas RTH publik serta RTH privat. Persentase minimal penyediaan RTH pada wilayah perkotaan adalah $30 \%$ (tiga puluh persen), terdiri atas $20 \%$ (dua puluh persen) RTH publik dan $10 \%$ (sepuluh persen) RTH privat.

RTH adalah ruang terbuka dengan vegetasi yang terletak di kawasan perkotaan. RTH memiliki fungsi sebagai area rekreasi, sosial budaya, estetika, fisik kota, ekologis, dan ekonomis bagi manusia maupun bagi kota tersebut (Setyani, Sitorus, \& Panuju, 2017). RTH merupakan ruang lapang dengan tanaman yang terletak di sepanjang jalan, bergerombol, taman, maupun hutan kota (Nugradi, 2009).

RTH adalah kawasan yang didominasi oleh tumbuhan yang dimanfaatkan sebagai tempat perlindungan habitat tertentu dan sarana rekreasi bagi masyarakat (Kusuma, Annas, Putri, Septianto, 2014). Maka, perencanaan RTH bertujuan untuk menjaga keseimbangan, keserasian, dan keselarasan antara lahan terbangun dan lahan tidak terbangun. Perencanaan RTH juga bertujuan untuk menjaga keseimbangan ekosistem, meningkatkan kualitas udara, serta meningkatkan keindahan kota (Samsudi, 2010). RTH pada suatu lokasi dapat dimanfaatkan sebagai tempat bagi masyarakat untuk melakukan aktivitas secara individu ataupun berkelompok (Sasongko, Kurniawati, Siregar, 2017). RTH juga memiliki peran dalam menjaga fungsi ekologis lingkungan dan estetika kawasan tersebut (Santoso, Hidayah, Sumardjito, 2012).

Kabupaten Malang memiliki kawasan RTH baik RTH privat maupun RTH publik. RTH privat Kabupaten Malang terdiri atas kebun milik masyarakat yang ditanami tumbuhan. RTH publik Kabupaten Malang terdiri atas taman kota, taman pemakaman umum, dan jalur hijau (Rencana Tata Ruang Wilayah (RTRW) Kabupaten Malang Tahun 2010-2030). Pemerintah Kabupaten Malang berupaya untuk memenuhi kebutuhan penyediaan RTH dengan melakukan pengadaan berbagai tipe RTH yang tersebar di seluruh wilayah Kabupaten Malang. RTRW Kabupaten Malang Tahun 2010-2030 menyebutkan bahwa upaya yang dilakukan dalam pemenuhan kebutuhan penyediaan RTH, yaitu penetapan luasan RTH perkotaan minimum $30 \%$, pengembangan jenis RTH, dan pengadaan RTH publik aktif berupa taman dan hutan kota.

Ibukota Kabupaten Malang yaitu Kecamatan Kepanjen memiliki tujuan penataan ruang Bagian Wilayah Perkotaan (BWP) Kepanjen sebagai pusat pemerintahan yang hijau, nyaman, dan maju. Salah satu prinsip penataan ruang BWP Kepanjen adalah tersedianya RTH yang memadai sesuai dengan acuan peraturan perundang-undangan yang berlaku (Rencana Detail Tata Ruang (RDTR) BWP Kepanjen Tahun 2014-2034), sehingga setiap desa/kelurahan di Kecamatan Kepanjen perlu untuk menyediakan RTH publik aktif minimal seluas 0,00003 ha untuk setiap jiwa. Pemenuhan RTH tersebut bertujuan untuk menjaga keseimbangan dan melindungi alam (Sumarauw, 2016).

RTH publik aktif merupakan RTH yang digunakan oleh pengunjung untuk melakukan aktivitas tertentu. RTH publik aktif yang memiliki kualitas baik ditunjukkan dengan lama waktu yang dihabiskan oleh pengunjung di RTH tersebut (Nasution \& Zahrah, 2014). RTH publik aktif merupakan sarana yang dimanfaatkan oleh masyarakat sebagai tempat bersantai dan melakukan berbagai aktivitas, sehingga dalam perencanaannya perlu untuk mempertimbangkan persepsi masyarakat dalam rangka menjalankan fungsinya untuk melayani masyarakat (Suhasman, Agussalim, \& Yusuf, 2017).

Data dari Dinas Perumahan, Kawasan Permukiman dan Cipta Karya Kabupaten Malang (2017) menunjukkan bahwa Kecamatan Kepanjen belum memenuhi persentase minimal penyediaan RTH publik, khususnya RTH publik aktif. Kecamatan Kepanjen memiliki RTH publik aktif seluas 3,00 ha dengan jumlah penduduk sebanyak 106.647 jiwa. RTH publik aktif berada pada tiga desa/kelurahan, yaitu Desa Kedungpedaringan, Kelurahan Kepanjen, dan Desa Ngadilangkung. Jenis RTH publik aktif di Kecamatan Kepanjen adalah RTH taman. RTH publik aktif di Kecamatan Kepanjen merupakan RTH yang memiliki fungsi ekologis, fungsi sosial dan budaya, dan fungsi estetika.

Berdasarkan penjelasan sebelumnya, dapat disimpulkan bahwa perlu adanya penelitian untuk mengevaluasi kebutuhan RTH publik aktif di Kecamatan Kepanjen. Melalui penelitian ini, akan disusun rekomendasi penyediaan lokasi RTH 
publik aktif di Kecamatan Kepanjen berdasarkan persepsi masyarakat.

\section{METODE PENELITIAN}

\section{Lokasi Penelitian}

Lokasi penelitian berada di Kecamatan Kepanjen, Kabupaten Malang dengan luas wilayah 4.625 ha. Berikut merupakan batas administrasi dari Kecamatan Kepanjen.

Sebelah Utara : Kecamatan Ngajum dan Kecamatan Pakisaji

Sebelah Selatan: Kecamatan Pagelaran dan Kecamatan Pagak

Sebelah Barat : Kecamatan Ngajum Kecamatan Kromengan
Sebelah Timur : Kecamatan Gondanglegi dan Kecamatan Bululawang

\section{Variabel Penelitian}

Variabel penelitian adalah sesuatu yang digunakan oleh peneliti sebagai objek untuk dipelajari. Peneliti dapat memperoleh data yang dibutuhkan serta dapat menarik kesimpulan dari penelitian yang telah dilakukan. Variabel penelitian adalah sifat suatu benda yang akan dipelajari dalam penelitian. Variabel penelitian merupakan segala sesuatu yang membuat peneliti segera ingin mempelajarinya dan menarik kesimpulan dari variabel-variabel tersebut. dan Variabel penelitian yang digunakan dalam penelitian ini adalah sebagai berikut.

Tabel 1. Variabel Penelitian

\begin{tabular}{|c|c|c|c|}
\hline Tujuan & Variabel & Indikator & Parameter \\
\hline \multirow[t]{2}{*}{$\begin{array}{l}\text { Mengevaluasi kebutuhan RTH publik aktif di } \\
\text { Kecamatan Kepanjen, Kabupaten Malang. }\end{array}$} & Luas & Luas RTH Publik Aktif & $\begin{array}{l}\text { Luas RTH publik aktif }\left(\mathrm{m}^{2}\right) \text {, dengan } \\
\text { klasifikasi: } \\
\text { 1. Taman RT }\left(250 \mathrm{~m}^{2}\right) \\
\text { 2. Taman RW }\left(1.250 \mathrm{~m}^{2}\right) \\
\text { 3. Taman Kelurahan }\left(9.000 \mathrm{~m}^{2}\right) \\
\text { 4. Taman Kecamatan }\left(24.000 \mathrm{~m}^{2}\right) \\
\text { 5. Taman Kota }\left(144.000 \mathrm{~m}^{2}\right)\end{array}$ \\
\hline & Sebaran & $\begin{array}{lll}\text { Lokasi } & \text { RTH } & \text { Publik } \\
\text { Aktif } & & \end{array}$ & $\begin{array}{l}\text { Lokasi RTH publik aktif, dengan } \\
\text { klasifikasi: } \\
\text { 1. Taman RT (di tengah lingkungan } \\
\text { RT) } \\
\text { 2. Taman RW (di pusat kegiatan RW) } \\
\text { 3. Taman Kelurahan (dikelompokkan } \\
\text { dengan sekolah/pusat kelurahan) } \\
\text { 4. Taman Kecamatan (dikelompokkan } \\
\text { dengan sekolah/pusat kecamatan) } \\
\text { 5. Taman kota (di pusat wilayah/kota) }\end{array}$ \\
\hline \multirow{10}{*}{$\begin{array}{l}\text { Menyusun rekomendasi penyediaan RTH } \\
\text { publik aktif di Kecamatan Kepanjen, } \\
\text { Kabupaten Malang. }\end{array}$} & Luas & Bobot Luas Lokasi & $\begin{array}{l}\text { Hasil pembobotan berdasarkan pendapat } \\
\text { ahli }\end{array}$ \\
\hline & $\begin{array}{l}\text { Kemiringan } \\
\text { Lereng }\end{array}$ & $\begin{array}{l}\text { Bobot Persentase } \\
\text { Kemiringan Lereng }\end{array}$ & $\begin{array}{l}\text { Hasil pembobotan berdasarkan pendapat } \\
\text { ahli }\end{array}$ \\
\hline & $\begin{array}{l}\text { Penggunaan } \\
\text { Lahan }\end{array}$ & $\begin{array}{l}\text { Bobot Jenis Guna } \\
\text { Lahan di Sekitar Lokasi }\end{array}$ & \\
\hline & $\begin{array}{l}\text { Kepadatan } \\
\text { Penduduk }\end{array}$ & $\begin{array}{l}\text { Bobot Tingkat } \\
\text { Kepadatan Penduduk }\end{array}$ & \\
\hline & Aksesibilitas & Bobot Hierarki Jalan & \\
\hline & $\begin{array}{l}\text { Jarak terhadap } \\
\text { Pusat Kota }\end{array}$ & $\begin{array}{l}\text { Bobot Jarak terhadap } \\
\text { Pusat Kota }\end{array}$ & \\
\hline & $\begin{array}{l}\text { Penggunaan dan } \\
\text { Aktivitas }\end{array}$ & $\begin{array}{l}\text { Bobot Penggunaan dan } \\
\text { Aktivitas }\end{array}$ & $\begin{array}{l}\text { Hasil pembobotan berdasarkan pendapat } \\
\text { ahli }\end{array}$ \\
\hline & Kenyamanan & Bobot Kenyamanan & $\begin{array}{l}\text { Hasil pembobotan berdasarkan pendapat } \\
\text { ahli }\end{array}$ \\
\hline & $\begin{array}{ll}\text { Akses } & \text { dan } \\
\text { Jaringan } & \\
\end{array}$ & $\begin{array}{lll}\text { Bobot Akses dan } \\
\text { Jaringan }\end{array}$ & $\begin{array}{l}\text { Hasil pembobotan berdasarkan pendapat } \\
\text { ahli }\end{array}$ \\
\hline & Keramahan & Bobot Keramahan & $\begin{array}{l}\text { Hasil pembobotan berdasarkan pendapat } \\
\text { ahli }\end{array}$ \\
\hline
\end{tabular}

\section{Teknik Pengumpulan Data}

Pengumpulan data dapat dilakukan dalam berbagai lokasi, sumber, dan cara. Pada penelitian ini, pengumpulan data melalui survei primer dilakukan dengan menggunakan observasi dan kuesioner. Sementara itu, survei sekunder diperoleh melalui studi literatur serta instansi- instansi pada bidang perencanaan, khususnya perencanaan RTH publik aktif.

Tabel 2. Kebutuhan Data

\begin{tabular}{lll}
\hline $\begin{array}{c}\text { Teknik } \\
\text { Pengumpulan Data }\end{array}$ & \multicolumn{1}{c}{ Data } \\
\hline Survei Primer & 1. & Luas RTH Publik Aktif \\
& 2. & Lokasi RTH Publik Aktif \\
& 3. & Hasil Penilaian Faktor Penentuan \\
& & Lokasi RTH Publik Aktif \\
\hline
\end{tabular}




\begin{tabular}{lll}
\hline $\begin{array}{c}\text { Teknik } \\
\text { Pengumpulan Data }\end{array}$ & \multicolumn{2}{c}{ Data } \\
\hline & 4. & Hasil Penilaian Kriteria \\
& & Penyediaan Lokasi RTH Publik \\
& Aktif & \\
\hline Survei Sekunder & 1. & Luas RTH Publik Aktif \\
& 2. & Lokasi RTH Publik Aktif \\
& 3. & Luas Wilayah \\
& 4. & Jumlah Penduduk \\
\hline
\end{tabular}

\section{Populasi dan Sampel}

\section{a) Populasi}

Populasi yang ditetapkan oleh peneliti untuk dipelajari pada penelitian ini adalah seluruh masyarakat Kecamatan Kepanjen. Jumlah penduduk di Kecamatan Kepanjen pada tahun 2019 sebanyak 119.382 jiwa.

\section{b) Sampel}

Penelitian ini menggunakan teknik sampling probability sampling berupa simple random sampling karena pemilihan sampel dilakukan secara acak tanpa memperhatikan strata dari populasi tersebut.

Kuesioner penyediaan RTH publik aktif ditujukan kepada masyarakat Kecamatan Kepanjen. Sampel untuk menentukan jumlah responden kuesioner penyediaan RTH publik aktif menggunakan rumus Isaac \& Michael yang diperkenalkan pada tahun 1981. Penelitian ini menggunakan rumus Isaac \& Michael karena jumlah populasi telah diketahui, yaitu sebanyak 105.094 jiwa. Selain itu, penelitian ini juga menggunakan perhitungan proporsi responden pada setiap desa/kelurahan karena diharapkan penyediaan RTH publik aktif dapat memenuhi kebutuhan serta harapan dari masyarakat pada masing-masing desa/kelurahan.

Tabel 3. Sampel

\begin{tabular}{lrrr}
\hline Kelurahan & $\begin{array}{c}\text { Jumlah } \\
\text { Penduduk } \\
\text { (jiwa) }\end{array}$ & $\begin{array}{c}\text { Prop } \\
\text { orsi }\end{array}$ & $\begin{array}{c}\text { Jumlah } \\
\text { Sampel (jiwa) }\end{array}$ \\
\hline Jenggolo & 5.715 & 0,05 & 13 \\
Sengguruh & 8.176 & 0,08 & 19 \\
Kemiri & 14.643 & 0,14 & 32 \\
Tegalsari & 6.784 & 0,06 & 16 \\
Mangunrejo & 3.706 & 0,04 & 9 \\
Panggungrejo & 4.003 & 0,04 & 9 \\
Penarukan & 5.696 & 0,05 & 13 \\
Cepokomulyo & 4.242 & 0,04 & 10 \\
Kepanjen & 3.276 & 0,03 & 8 \\
Talangagung & 9.263 & 0,09 & 21 \\
Dilem & 8.657 & 0,08 & 20 \\
Ardirejo & 6.675 & 0,06 & 16 \\
Sukoraharjo & 8.011 & 0,08 & 19 \\
Curungrejo & 6.128 & 0,06 & 14 \\
Jatirejoyoso & 6.039 & 0,06 & 14 \\
Mojosari & 4.080 & 0,04 & 10 \\
\hline Kecamatan & 105.094 & 1,00 & 250 \\
Kepanjen & & & \\
\hline
\end{tabular}

\section{Teknik Analisis Data}

Penelitian ini menggunakan dua jenis analisis.

1. Analisis Kebutuhan RTH Publik Aktif

Analisis kebutuhan RTH publik aktif merupakan analisis yang digunakan untuk menentukan kebutuhan RTH publik aktif pada suatu wilayah berdasarkan Peraturan Menteri Pekerjaan Umum Nomor 5 Tahun 2008 tentang Pedoman Penyediaan dan Pemanfaatan Ruang Terbuka Hijau di Kawasan Perkotaan. Langkah-langkah dalam analisis ini, yaitu:

a. Menghitung kebutuhan RTH publik pada setiap desa/kelurahan di Kecamatan Kepanjen dengan rumus sebagai berikut.

Kebutuhan RTH Publik $=\mathbf{2 0} \% \times$ Luas Wilayah dengan:

$20 \%=$ Standar kebutuhan RTH publik daerah perkotaan berdasarkan Peraturan Menteri Pekerjaan Umum Nomor 5 Tahun 2008 tentang Pedoman Penyediaan dan Pemanfaatan Ruang Terbuka Hijau di Kawasan Perkotaan

b. Menghitung kebutuhan RTH publik aktif pada setiap desa/kelurahan di Kepanjen dengan ketentuan sebagai berikut.

Tabel 4. Kebutuhan RTH Publik Aktif

\begin{tabular}{lll}
\hline $\begin{array}{c}\text { Unit } \\
\text { Lingkungan }\end{array}$ & Tipe RTH & \multicolumn{1}{c}{ Lokasi } \\
\hline 250 jiwa & Taman RT & $\begin{array}{l}\text { Di tengah } \\
\text { lingkungan RT }\end{array}$ \\
\hline 2.500 jiwa & Taman RW & $\begin{array}{l}\text { Di pusat kegiatan } \\
\text { RW }\end{array}$ \\
\hline 30.000 jiwa & Taman & $\begin{array}{l}\text { Dikelompokkan } \\
\text { dengan } \\
\text { sekolah/pusat } \\
\text { kelurahan }\end{array}$ \\
& Kelurahan & $\begin{array}{l}\text { Dikelompokkan } \\
\text { dengan } \\
\text { sekolah/pusat } \\
\text { kecamatan }\end{array}$ \\
& Taman & Kecamatan \\
& & $\begin{array}{l}\text { Di pusat } \\
\text { wilayah/kota }\end{array}$ \\
\hline 480.000 jiwa & Taman Kota & \\
\hline
\end{tabular}

2. Analisis Faktor Prioritas Penyediaan RTH Publik Aktif

Analisis faktor prioritas penyediaan RTH publik aktif pada penelitian ini menggunakan teknik analisis AHP. Analisis Hierarki Proses (AHP) diperkenalkan pertama kali oleh Saaty (1980). AHP adalah suatu hierarki fungsional dengan masukan utamanya adalah persepsi manusia. AHP merupakan model pengambilan keputusan komprehensif. AHP memiliki pendekatan yang hampir sama dengan model perilaku politis. AHP dapat menyelesaikan masalah kompleks yang memiliki kriteria cukup banyak (Suryadi \& Ramadhani, 1998). Pada penelitian ini, AHP 
digunakan untuk menentukan faktor prioritas yang akan menjadi dasar dalam penyusunan rekomendasi penyediaan RTH publik aktif di Kecamatan Kepanjen. Pengambil keputusan untuk AHP pada penelitian ini, antara lain:

a. Satu orang staff Dinas Perumahan, Kawasan Permukiman, dan Cipta Karya Kabupaten Malang.

b. Satu orang ahli perencanaan wilayah dan kota.

c. Satu orang ahli arsitektur lansekap.

\section{HASIL DAN PEMBAHASAN}

\section{Kebutuhan RTH Publik Aktif}

Perhitungan kebutuhan RTH publik aktif didasarkan terhadap Peraturan Menteri Pekerjaan Umum Nomor 5 Tahun 2008 tentang Pedoman Penyediaan dan Pemanfaatan Ruang Terbuka Hijau di Kawasan Perkotaan. Peraturan perundang-undangan tersebut menyebutkan bahwa setiap desa/kelurahan perlu untuk menyediakan RTH publik aktif minimal seluas 0,00003 ha untuk setiap jiwa.

Tabel 5. Kebutuhan RTH Publik Aktif

\begin{tabular}{|c|c|c|c|c|c|}
\hline Desa/Kelurahan & $\begin{array}{c}\text { Jumlah } \\
\text { Penduduk } \\
\text { (jiwa) }\end{array}$ & $\begin{array}{l}\text { Luas Minimal RTH } \\
\text { Publik Aktif (ha) }\end{array}$ & $\begin{array}{c}\text { Ketersediaan RTH } \\
\text { Publik Aktif (ha) }\end{array}$ & $\begin{array}{l}\text { Kebutuhan RTH } \\
\text { Publik Aktif (ha) }\end{array}$ & Klasifikasi \\
\hline $\mathbf{a}$ & b & $c=b * 0,00003$ & d & $\mathrm{e}=\mathrm{d}-\mathrm{c}$ & f \\
\hline Jenggolo & 5.715 & 0,17 & 0,00 & $-0,17$ & Tidak Memenuhi \\
\hline Sengguruh & 8.176 & 0,25 & 0,00 & $-0,25$ & Tidak Memenuhi \\
\hline Kemiri & 14.643 & 0,44 & 0,00 & $-0,44$ & Tidak Memenuhi \\
\hline Tegalsari & 6.784 & 0,20 & 0,00 & $-0,20$ & Tidak Memenuhi \\
\hline Mangunrejo & 3.706 & 0,11 & 0,00 & $-0,11$ & Tidak Memenuhi \\
\hline Panggungrejo & 4.003 & 0,12 & 0,00 & $-0,12$ & Tidak Memenuhi \\
\hline Kedungpedaringan & 6.718 & 0,20 & 1,35 & 1,18 & Memenuhi \\
\hline Penarukan & 5.696 & 0,17 & 0,00 & $-0,17$ & Tidak Memenuhi \\
\hline Cepokomulyo & 4.242 & 0,13 & 0,00 & $-0,13$ & Tidak Memenuhi \\
\hline Kepanjen & 3.276 & 0,10 & 0,04 & $-0,06$ & Tidak Memenuhi \\
\hline Talangagung & 9.263 & 0,28 & 0,00 & $-0,28$ & Tidak Memenuhi \\
\hline Dilem & 8.657 & 0,26 & 0,00 & $-0,26$ & Tidak Memenuhi \\
\hline Ardirejo & 6.675 & 0,20 & 0,00 & $-0,20$ & Tidak Memenuhi \\
\hline Sukoraharjo & 8.011 & 0,24 & 0,00 & $-0,24$ & Tidak Memenuhi \\
\hline Curungrejo & 6.128 & 0,18 & 0,00 & $-0,18$ & Tidak Memenuhi \\
\hline Jatirejoyoso & 6.039 & 0,18 & 0,00 & $-0,18$ & Tidak Memenuhi \\
\hline Ngadilangkung & 7.570 & 0,23 & 1,61 & 1,38 & Memenuhi \\
\hline Mojosari & 4.080 & 0,12 & 0,00 & $-0,12$ & Tidak Memenuhi \\
\hline $\begin{array}{c}\text { Kecamatan } \\
\text { Kepanjen }\end{array}$ & 119.382 & 3,58 & 3,00 & $-0,58$ & $\begin{array}{l}\text { Tidak } \\
\text { Memenuhi }\end{array}$ \\
\hline
\end{tabular}

Kecamatan Kepanjen hanya memiliki dua desa/kelurahan yang telah menyediakan RTH publik aktif, yaitu Desa Ngadilangkung dan Desa Kedungpedaringan. Luas RTH publik aktif pada kedua desa/kelurahan tersebut, yaitu 3,00 ha. Desa Ngadilangkung memiliki Taman Puspa dan Taman Kehati dengan total luas 1,61 ha, sedangkan Desa Kedungpedaringan memiliki Taman Bumi Arema dan Taman Lalu Lintas dengan total luas 1,35 ha.

Lokasi RTH publik aktif tersebut juga belum tersebar secara merata karena hanya terdapat pada dua desa saja. Hal ini dapat menyebabkan degradasi kualitas lingkungan perkotaan di Kecamatan Kepanjen, sehingga perlu untuk dilaksanakan penambahan luas RTH publik aktif guna menjaga dan meningkatkan kualitas lingkungan perkotaan.

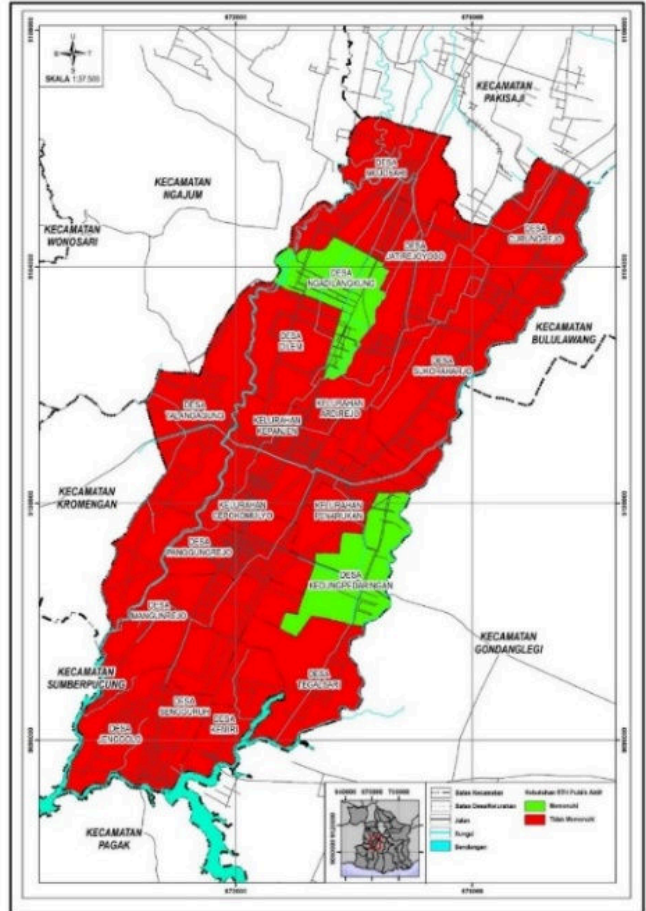

Gambar 1. Peta Kebutuhan RTH Publik Aktif di Kecamatan Kepanjen 


\section{Faktor Prioritas Penyediaan RTH Publik Aktif}

a) Berdasarkan Persepsi Masyarakat

1. Luas

Penyediaan RTH publik aktif dapat berupa taman RT, taman RW, taman kelurahan, taman kecamatan, dan taman kota. Luas lahan yang dibutuhkan dalam penyediaan RTH publik aktif tersebut telah diatur dalam Peraturan Menteri Pekerjaan Umum Nomor 5 Tahun 2008 tentang Pedoman Penyediaan dan Pemanfaatan Ruang Terbuka Hijau di Kawasan Perkotaan.

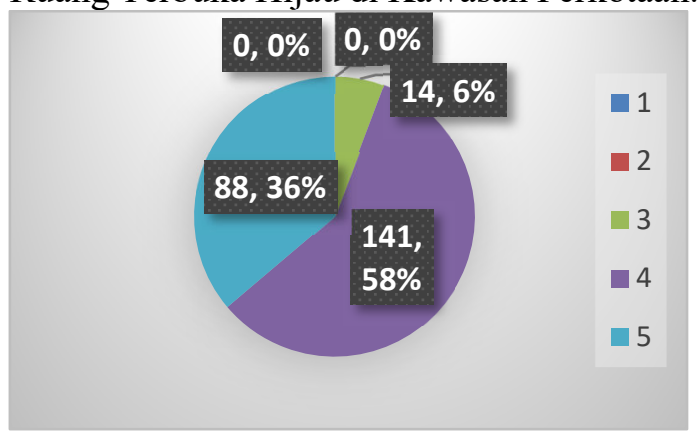

Gambar 2. Nilai Kepentingan Luas

Masyarakat Kecamatan Kepanjen sebanyak 141 orang berpendapat bahwa luas lokasi memiliki nilai kepentingan sebesar 4 atau penting untuk dipertimbangkan dalam penyediaan RTH publik aktif.

\section{Kemiringan Lereng}

RTH publik aktif idealnya berada pada kemiringan lereng datar (0-8\%) dan landai (8-15\%). Hal ini dikarenakan RTH publik aktif ini merupakan RTH yang dimanfaatkan oleh masyarakat untuk melakukan aktivitasaktivitas tertentu, sehingga membutuhkan lokasi dengan kemiringan lereng yang tidak curam.

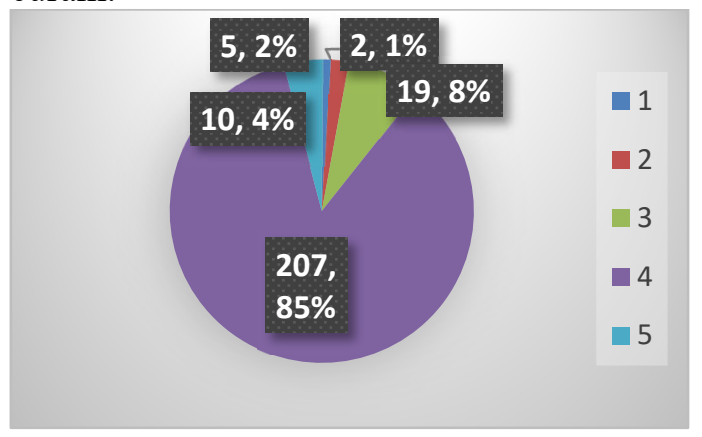

Gambar 3. Nilai Kepentingan Kemiringan Lereng

Masyarakat Kecamatan Kepanjen sebanyak 207 orang berpendapat bahwa kemiringan lereng memiliki nilai kepentingan sebesar 4 atau penting untuk dipertimbangkan dalam penyediaan RTH publik aktif. Sementara itu, sebanyak 5 orang berpendapat bahwa kemiringan lereng tidak penting untuk dipertimbangkan serta sebanyak 2 orang berpendapat bahwa kemiringan lereng sangat tidak penting untuk dipertimbangkan.

3. Penggunaan Lahan di Sekitar Lokasi

Penyediaan RTH publik aktif diutamakan berada di sekitar lokasi dengan guna lahan berupa perdagangan dan jasa. Penyediaan RTH publik aktif sebaiknya juga berada di dekat permukiman, sehingga mudah untuk diakses oleh masyarakat sekitar.

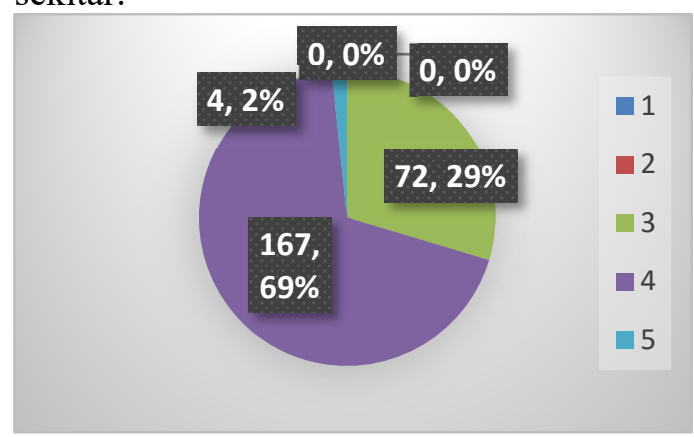

Gambar 4. Nilai Kepentingan Penggunaan Lahan di Sekitar Lokasi

Masyarakat Kecamatan Kepanjen sebanyak 119 orang berpendapat bahwa penggunaan lahan di sekitar lokasi memiliki nilai kepentingan sebesar 4 atau penting untuk dipertimbangkan dalam penyediaan RTH publik aktif.

4. Kepadatan Penduduk

Penyediaan RTH publik aktif diutamakan berada pada lokasi dengan kepadatan penduduk tinggi $>200$ jiwa/ha, sehingga RTH publik aktif dimanfaatkan dengan optimal.

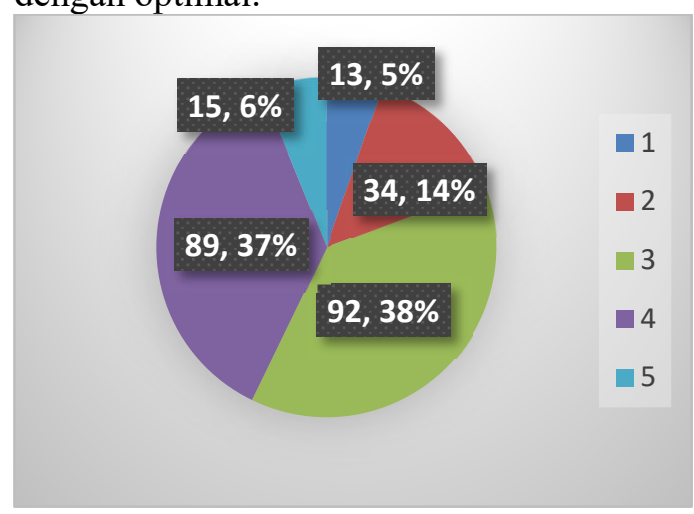

Gambar 5. Nilai Kepentingan Kepadatan Penduduk

Masyarakat Kecamatan Kepanjen sebanyak 92 orang berpendapat bahwa kepadatan penduduk di sekitar lokasi memiliki nilai kepentingan sebesar 3 atau 
cukup penting untuk dipertimbangkan dalam penyediaan RTH publik aktif. Sementara itu, banyak masyarakat Kecamatan Kepanjen yang berpendapat bahwa kepadatan penduduk di sekitar lokasi bukan merupakan faktor yang penting untuk dipertimbangkan. Sebanyak 34 orang berpendapat bahwa kepadatan penduduk di sekitar lokasi tidak penting untuk dipertimbangkan serta sebanyak 13 orang berpendapat bahwa kepadatan penduduk di sekitar lokasi sangat tidak penting untuk dipertimbangkan.

5. Aksesibilitas Lahan

Penyediaan RTH publik aktif harus memilih lokasi dengan tingkat aksesibilitas yang tinggi, sehingga mudah untuk diakses oleh masyarakat. Tingkat aksesibilitas ini dapat dinilai melalui hierarki jalan di sekitar lokasi penyediaan RTH. Semakin tinggi hierarki jalan pada lokasi, maka tingkat aksesibilitas menuju lokasi tersebut.

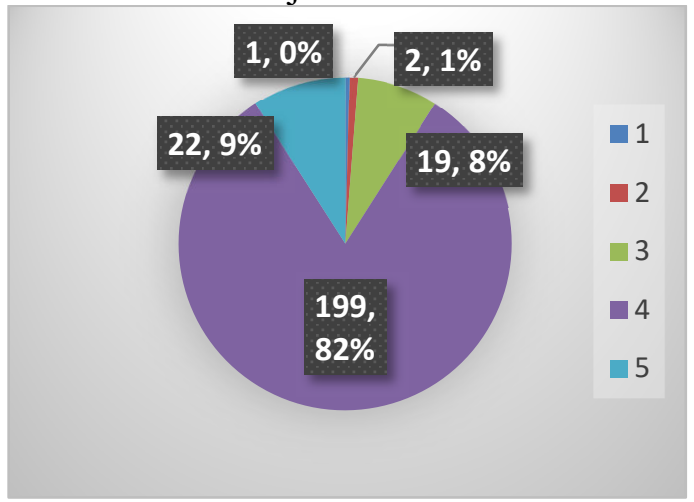

Gambar 6. Nilai Kepentingan Aksesibilitas Lahan

Masyarakat Kecamatan Kepanjen sebanyak 199 orang berpendapat bahwa aksesibilitas lahan memiliki nilai kepentingan sebesar 4 atau penting untuk dipertimbangkan dalam penyediaan RTH publik aktif. Sementara itu, sebanyak 2 orang berpendapat bahwa aksesibilitas lahan tidak penting untuk dipertimbangkan serta sebanyak 1 orang berpendapat bahwa aksesibilitas lahan sangat tidak penting untuk dipertimbangkan.

6. Jarak terhadap Pusat Kota

Penyediaan RTH publik aktif juga mempertimbangkan jarak lokasi menuju pusat kota. Apabila lokasi penyediaan RTH publik aktif semakin dekat dengan pusat kota, maka masyarakat juga akan semakin mudah untuk menjangkau RTH publik aktif tersebut.

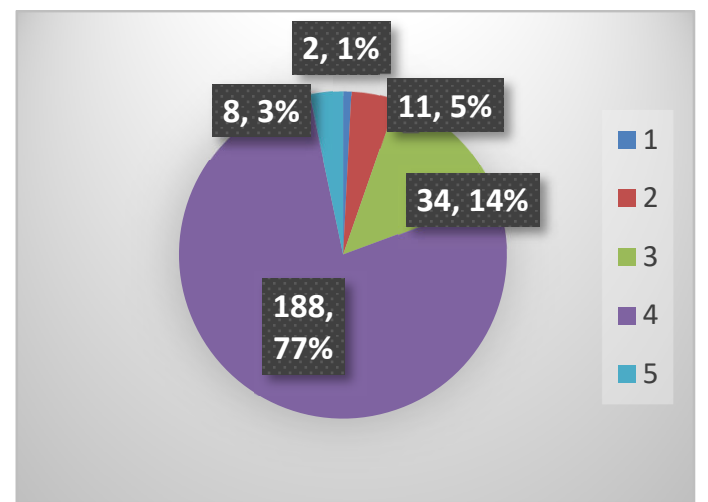

Gambar 7. Nilai Kepentingan Jarak terhadap Pusat Kota

Masyarakat Kecamatan Kepanjen sebanyak 188 orang berpendapat bahwa luas lokasi memiliki nilai kepentingan sebesar 4 atau penting untuk dipertimbangkan dalam penyediaan RTH publik aktif.

7. Penggunaan dan Aktivitas

RTH publik aktif dengan kualitas baik merupakan RTH publik aktif yang mampu menyediakan beragam pilihan aktivitas bagi pengunjung. Semakin banyak aktivitas yang dilakukan di ruang publik akan meningkatkan kualitas ruang publik. Semakin banyak pengunjung yang datang secara berkelompok juga akan meningkatkan kualitas ruang publik. Hal ini menunjukkan bahwa ruang publik tersebut digunakan untuk berinteraksi dengan orang lain.

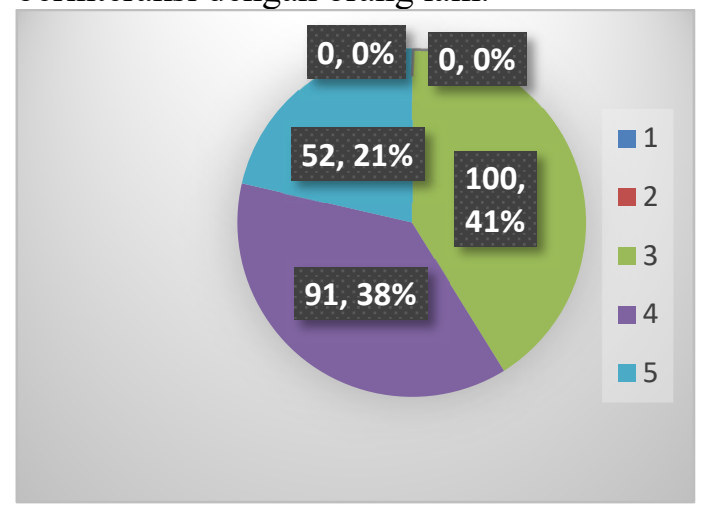

Gambar 8. Nilai Kepentingan Penggunaan dan Aktivitas

Masyarakat Kecamatan Kepanjen sebanyak 100 orang berpendapat bahwa penggunaan dan aktivitas memiliki nilai kepentingan sebesar 4 atau penting untuk dipertimbangkan dalam penyediaan RTH publik aktif.

\section{Kenyamanan}

Kenyamanan adalah elemen yang mencakup tentang tingkat kepentingan penyediaan fasilitas yang menunjang keamanan, kebersihan, dan ketersediaan tempat duduk pada RTH publik aktif. 
Fasilitas yang penting untuk disediakan pada RTH publik aktif antara lain fasilitas bagi pengunjung wanita, fasilitas tempat duduk, fasilitas kebersihan, fasilitas spot foto, dan fasilitas jalur pejalan kaki. Semakin lengkap fasilitas yang disediakan oleh RTH publik, semakin baik kualitas RTH publik aktif tersebut.

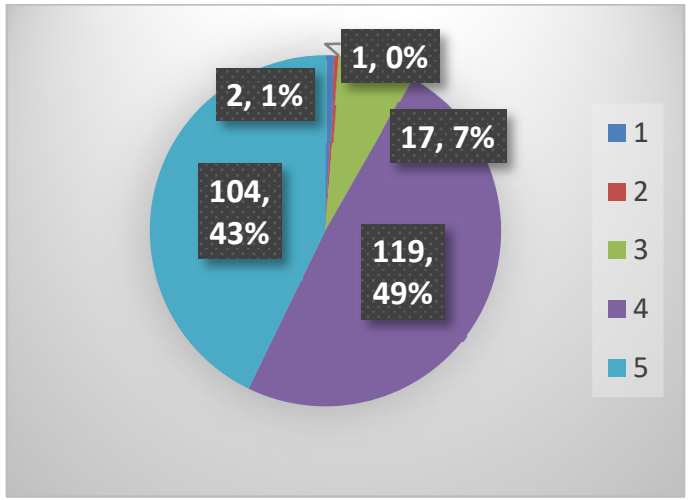

Gambar 9. Nilai Kepentingan Kenyamanan

Masyarakat Kecamatan Kepanjen sebanyak 167 orang berpendapat bahwa kenyamanan memiliki nilai kepentingan sebesar 4 atau penting untuk dipertimbangkan dalam penyediaan RTH publik aktif.

\section{Akses dan Jaringan}

RTH publik aktif dengan kualitas baik merupakan RTH publik aktif yang memiliki kemudahan akses. Kemudahan akses menuju ruang publik ditandai dengan adanya tempat parkir yang luas dan dilewati oleh berbagai transportasi umum. Kemudahan akses juga dapat dinilai melalui keberadaan jalur pejalan kaki yang juga dapat diakses oleh penyandang cacat.

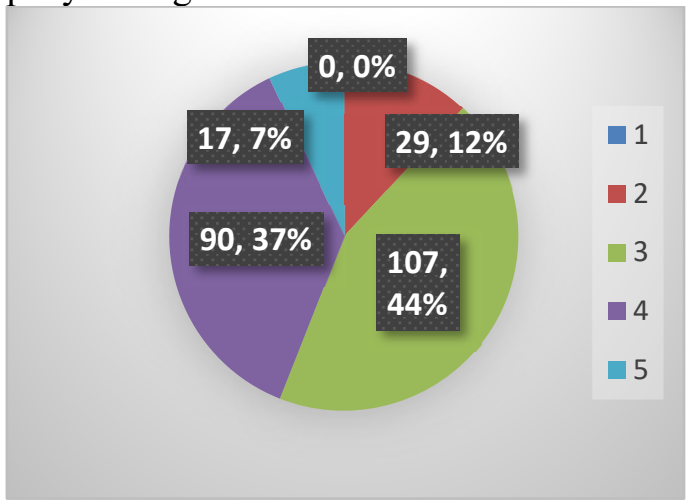

Gambar 10. Nilai Kepentingan Akses dan Jaringan

Masyarakat Kecamatan Kepanjen sebanyak 107 orang berpendapat bahwa akses dan jaringan memiliki nilai kepentingan sebesar 4 atau penting untuk dipertimbangkan dalam penyediaan RTH publik aktif.

\section{Keramahan}

Keramahan adalah elemen yang dapat dinilai dari tingkat kenyamanan masyarakat dalam berinteraksi serta kenyamanan masyarakat dalam beraktivitas di ruang publik tersebut. Fasilitas yang penting untuk disediakan pada RTH publik aktif antara lain fasilitas untuk pengunjung yang datang bersama teman maupun keluarga serta fasilitas yang dapat menunjang interaksi antar pengunjung. Semakin sering pengunjung berinteraksi, semakin baik kualitas RTH publik aktif tersebut.

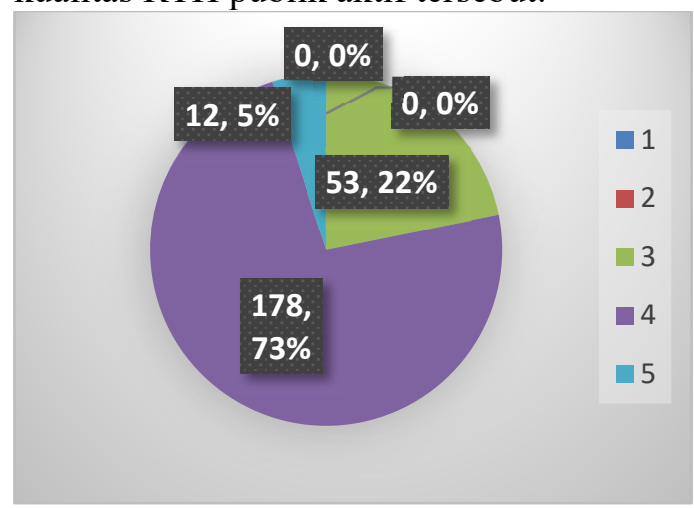

Gambar 11. Nilai Kepentingan Keramahan

Masyarakat Kecamatan Kepanjen sebanyak 178 orang berpendapat bahwa keramahan memiliki nilai kepentingan sebesar 4 atau penting untuk dipertimbangkan dalam penyediaan RTH publik aktif.

\section{b) Berdasarkan Pendapat Ahli}

Faktor prioritas penyediaan RTH publik aktif ditentukan dengan menggunakan AHP. AHP digunakan untuk menentukan bobot dari setiap faktor penyediaan RTH publik aktif. Penentuan lokasi potensial RTH publik aktif mempertimbangkan 10 faktor, yang terdiri atas enam faktor fisik dan empat faktor non fisik. Faktor fisik yang dipertimbangkan antara lain luas, kemiringan lereng, penggunaan lahan di sekitar lokasi, kepadatan penduduk, aksesibilitas lahan, dan jarak terhadap pusat kota. Faktor non fisik yang dipertimbangkan antara lain penggunaan dan aktivitas, kenyamanan, akses dan jaringan, dan keramahan. Penentuan bobot masing-masing faktor dilakukan dengan memberikan kuesioner kepada tiga orang pengambil keputusan, yaitu staff Dinas Perumahan, Kawasan Permukiman, dan Cipta Karya, ahli Perencanaan Wilayah dan Kota, dan ahli Arsitektur Lansekap. 


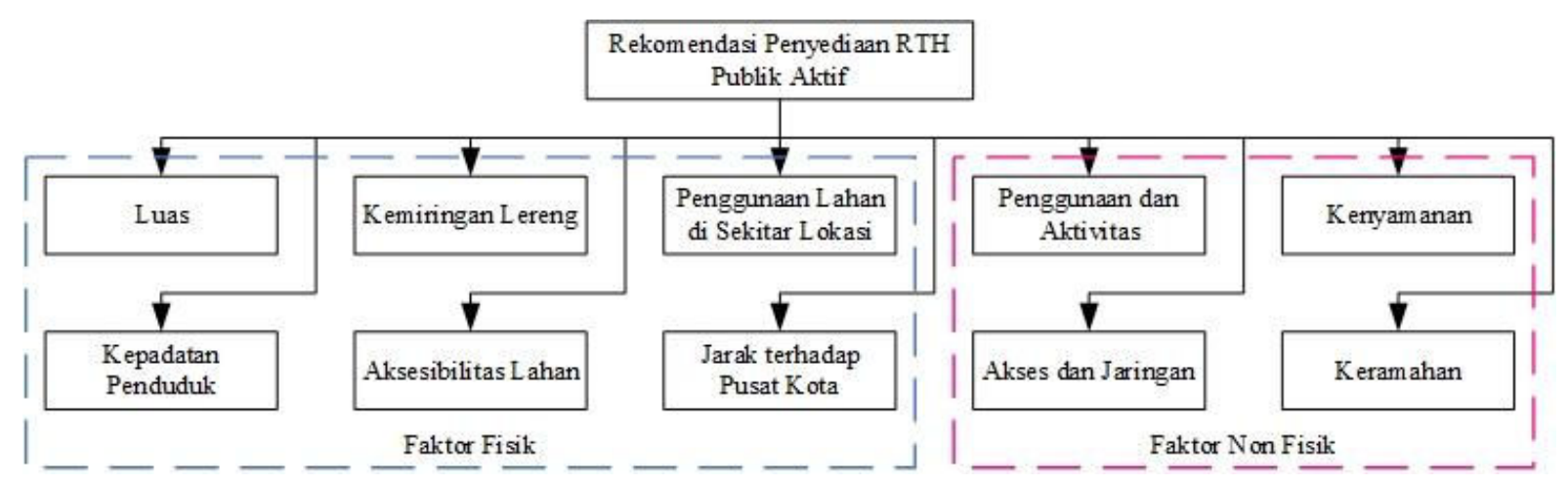

Gambar 12. Analisis Hierarki Proses

Berdasarkan hasil dari ketiga pengambil keputusan, yaitu staff Dinas Perumahan, Kawasan Permukiman, dan Cipta Karya, ahli Perencanaan Wilayah dan Kota, dan ahli Arsitektur Lansekap, maka didapatkan peringkat faktor penyediaan RTH publik aktif sebagai berikut.

Tabel 6. Bobot Faktor Penyediaan RTH Publik Aktif

\begin{tabular}{llr}
\hline & \multicolumn{1}{c}{ Faktor } & Bobot \\
\hline A & Luas & 0,065 \\
B & Kemiringan Lereng & 0,050 \\
C & Penggunaan Lahan di Sekitar Lokasi & 0,072 \\
D & Kepadatan Penduduk & 0,077 \\
E & Aksesiblitas Lahan & 0,103 \\
F & Jarak terhadap Pusat Kota & 0,108 \\
G & Penggunaan dan Aktivitas & 0,129
\end{tabular}

\begin{tabular}{clc}
\hline & \multicolumn{1}{c}{ Faktor } & Bobot \\
\hline H & Kenyamanan & 0,167 \\
I & Akses dan Jaringan & 0,137 \\
J & Keramahan & 0,094 \\
\hline \multicolumn{2}{r}{ Total } & $\mathbf{1 , 0 0}$ \\
\hline
\end{tabular}

Faktor non fisik berupa kenyamanan merupakan faktor prioritas dalam penyediaan RTH publik aktif. Kenyamanan adalah elemen yang mencakup tentang tingkat kepentingan penyediaan fasilitas yang menunjang keamanan, kebersihan, dan ketersediaan tempat duduk pada RTH publik aktif. Semakin lengkap fasilitas yang disediakan oleh RTH publik, semakin baik kualitas RTH publik aktif tersebut.

$\underline{\text { Tabel 7. Peringkat Faktor Penyediaan RTH Publik Aktif }}$

\begin{tabular}{|c|c|c|c|c|c|c|}
\hline & Faktor & $\begin{array}{l}\text { Staff Dinas Perumahan, } \\
\text { Kawasan Permukiman, } \\
\text { dan Cipta Karya }\end{array}$ & $\begin{array}{l}\text { Ahli Perencanaan } \\
\text { Wilayah dan Kota }\end{array}$ & $\begin{array}{c}\text { Ahli } \\
\text { Arsitektur } \\
\text { Lansekap }\end{array}$ & $\begin{array}{l}\text { Rata- } \\
\text { rata }\end{array}$ & Peringkat \\
\hline $\mathrm{H}$ & Kenyamanan & 0,1256 & 0,1639 & 0,2106 & 0,167 & 1 \\
\hline I & Akses dan Jaringan & 0,1115 & 0,2150 & 0,0838 & 0,137 & 2 \\
\hline G & $\begin{array}{l}\text { Penggunaan dan } \\
\text { Aktivitas }\end{array}$ & 0,1112 & 0,0847 & 0,1902 & 0,129 & 3 \\
\hline $\mathrm{F}$ & $\begin{array}{l}\text { Jarak terhadap } \\
\text { Pusat Kota }\end{array}$ & 0,0931 & 0,1600 & 0,0701 & 0,108 & 4 \\
\hline E & Aksesiblitas Lahan & 0,0897 & 0,1317 & 0,0866 & 0,103 & 5 \\
\hline $\mathrm{J}$ & Keramahan & 0,0706 & 0,0382 & 0,1723 & 0,094 & 6 \\
\hline D & $\begin{array}{l}\text { Kepadatan } \\
\text { Penduduk }\end{array}$ & 0,1017 & 0,0921 & 0,0366 & 0,077 & 7 \\
\hline C & $\begin{array}{l}\text { Penggunaan Lahan } \\
\text { di Sekitar Lokasi }\end{array}$ & 0,0922 & 0,0481 & 0,0752 & 0,072 & 8 \\
\hline A & Luas & 0,1039 & 0,0437 & 0,0488 & 0,065 & 9 \\
\hline $\mathrm{B}$ & Kemiringan Lereng & 0,1004 & 0,0226 & 0,0259 & 0,050 & 10 \\
\hline & Total & 1,00 & 1,00 & 1,00 & 1,00 & - \\
\hline
\end{tabular}

\section{Rekomendasi Penyediaan RTH Publik Aktif}

Penyediaan RTH publik aktif merupakan upaya untuk memenuhi persentase minimal RTH publik aktif sesuai dengan peraturan perundangundangan. Rekomendasi penyediaan RTH publik aktif disusun berdasarkan hasil analisis yang telah dilakukan pada tahapan sebelumnya.
Rekomendasi penyediaan RTH publik aktif didapatkan melalui AHP. Berdasarkan hasil analisis yang telah dilakukan, faktor utama yang perlu dipertimbangkan dalam penyediaan RTH publik aktif adalah faktor non fisik berupa kenyamanan. Berikut merupakan rekomendasi penyediaan RTH publik aktif berdasarkan persepsi masyarakat. 
Tabel 8. Rekomendasi Penyediaan RTH Publik Aktif

\begin{tabular}{|c|c|c|}
\hline Variabel & Eksisting & Rekomendasi \\
\hline Luas & $\begin{array}{l}\text { Luas lahan yang dapat dimanfaatkan sebagai RTH } \\
\text { publik aktif sebesar 3.078,81 ha. Sebagian besar } \\
\text { lahan tersebut memiliki guna lahan sawah. }\end{array}$ & $\begin{array}{l}\text { Penyediaan RTH publik aktif diutamakan berupa taman dengan } \\
\text { skala RT, sehingga lokasinya dapat dengan mudah dijangkau } \\
\text { karena taman ini ada di setiap RT. }\end{array}$ \\
\hline Kemiringan & Kecamatan Kepanjen sebagian besar memiliki & Penyediaan RTH publik aktif diutamakan berada pada \\
\hline Lereng & $\begin{array}{l}\text { kemiringan lereng } 0-8 \% \text { atau kemiringan lereng } \\
\text { datar. Hal ini menunjukkan bahwa lahan di } \\
\text { Kecamatan Kepanjen sangat sesuai untuk } \\
\text { dimanfaatkan sebagai RTH publik aktif. }\end{array}$ & $\begin{array}{l}\text { kemiringan lereng datar atau } 0-8 \% \text {. Apabila kemiringan lereng } \\
\text { pada RTH publik aktif lebih dari } 8 \% \text {, masyarakat menjadi } \\
\text { kurang tertarik untuk berkunjung ke RTH publik aktif karena } \\
\text { mereka akan lebih mudah merasa lelah ketika berjalan-jalan di } \\
\text { RTH publik aktif tersebut. }\end{array}$ \\
\hline $\begin{array}{l}\text { Penggunaan } \\
\text { Lahan di } \\
\text { Sekitar Lokasi }\end{array}$ & $\begin{array}{l}\text { Penggunaan lahan pada sekitar lokasi yang sesuai } \\
\text { untuk dimanfaatkan sebagai RTH publik aktif di } \\
\text { Kecamatan Kepanjen sebagian besar merupakan } \\
\text { perumahan. Hal ini dapat meningkatkan potensi } \\
\text { jumlah pengunjung yang akan datang apabila } \\
\text { disediakan RTH publik aktif baru. }\end{array}$ & $\begin{array}{l}\text { Penyediaan RTH publik aktif diutamakan berada di dekat } \\
\text { kantor pemerintahan khususnya TK dan SD, sehingga pada } \\
\text { saat pulang sekolah anak-anak dapat berkunjung ke RTH } \\
\text { publik aktif tersebut dengan mudah. }\end{array}$ \\
\hline $\begin{array}{l}\text { Kepadatan } \\
\text { Penduduk }\end{array}$ & $\begin{array}{l}\text { Kepadatan penduduk Kecamatan Kepanjen } \\
\text { termasuk ke dalam klasifikasi kepadatan penduduk } \\
\text { rendah, yaitu sebesar } 28 \text { jiwa/ha. Kepadatan } \\
\text { penduduk di Kecamatan Kepanjen terbilang rendah } \\
\text { karena masih banyak lahan berupa sawah yang ada } \\
\text { di kecamatan ini, sehingga luas lahan tidak } \\
\text { terbangun lebih luas daripada lahan terbangun. } \\
\end{array}$ & $\begin{array}{l}\text { Penyediaan RTH publik aktif diutamakan berada di tengah } \\
\text { permukiman, sehingga dapat dengan mudah dijangkau oleh } \\
\text { masyarakat. }\end{array}$ \\
\hline $\begin{array}{l}\text { Aksesibilitas } \\
\text { Lahan }\end{array}$ & $\begin{array}{l}\text { Kecamatan Kepanjen dilewati oleh jalan dengan } \\
\text { hierarki kolektor sekunder. Lahan di sekitar jalan } \\
\text { tersebut merupakan lahan yang sesuai untuk } \\
\text { dimanfaatkan sebagai RTH publik aktif baru karena } \\
\text { pengunjung dapat datang ke RTH publik aktif ini } \\
\text { dengan menggunakan berbagai macam moda } \\
\text { transportasi. }\end{array}$ & $\begin{array}{l}\text { Penyediaan RTH publik aktif diutamakan berada di pada jalan } \\
\text { dengan lebar lebih dari } 9 \text { m guna mempermudah aksesibilitas } \\
\text { menuju taman. }\end{array}$ \\
\hline $\begin{array}{l}\text { Jarak terhadap } \\
\text { Pusat Kota }\end{array}$ & $\begin{array}{l}\text { Pusat Kecamatan Kepanjen berada di Kelurahan } \\
\text { Kepanjen. Guna lahan di Kelurahan Kepanjen } \\
\text { didominasi oleh guna lahan permukiman seluas } \\
\text { 53,22 ha, sehingga sesuai untuk digunakan sebagai } \\
\text { lokasi pengembangan RTH publik aktif baru. }\end{array}$ & $\begin{array}{l}\text { Penyediaan RTH publik aktif diutamakan berada pada lokasi } \\
\text { yang berjarak } 751-1.000 \mathrm{~m} \text { dari pusat Kecamatan Kepanjen, } \\
\text { sehingga RTH publik aktif tersebut dapat tetap ramai oleh } \\
\text { pengunjung. }\end{array}$ \\
\hline $\begin{array}{l}\text { Penggunaan } \\
\text { dan Aktivitas }\end{array}$ & $\begin{array}{l}\text { Pada saat weekday, sebagian besar pengunjung } \\
\text { RTH publik aktif di Kecamatan Kepanjen } \\
\text { melakukan aktivitas berbincang dengan duduk. } \\
\text { Aktivitas ini dilakukan di lapangan terbuka dan } \\
\text { zona bermain anak-anak. Sementara itu, pada saat } \\
\text { weekend, sebagian besar pengunjung RTH publik } \\
\text { aktif di Kecamatan Kepanjen melakukan aktivitas } \\
\text { bermain, sehingga banyak pengunjung yang } \\
\text { berkumpul di zona bermain anak. }\end{array}$ & $\begin{array}{l}\text { RTH publik aktif diutamakan untuk menyediakan ruang } \\
\text { bermain anak mengingat sebagian besar pengunjung RTH } \\
\text { publik aktif di Kecamatan Kepanjen adalah pengunjung dengan } \\
\text { usia anak-anak. Selain itu, RTH publik aktif juga diutamakan } \\
\text { untuk menyediakan fasilitas seperti WC umum dan lahan } \\
\text { parkir untuk menunjang pengunjung dalam beraktivitas di RTH } \\
\text { publik aktif tersebut. }\end{array}$ \\
\hline Kenyamanan & $\begin{array}{l}\text { Fasilitas yang disediakan pada masing-masing RTH } \\
\text { publik aktif masih belum mencukupi. Selain itu, } \\
\text { banyak fasilitas yang telah mengalami kerusakan, } \\
\text { seperti tempat duduk. Banyak dari tempat duduk } \\
\text { yang disediakan di taman sudah tidak dapat } \\
\text { digunakan lagi karena mengalami pelapukan. }\end{array}$ & $\begin{array}{l}\text { Kenyamanan merupakan faktor utama dalam penyediaan RTH } \\
\text { publik aktif, sehingga penyediaan RTH publik aktif harus } \\
\text { mempertimbangkan tiga aspek yang menunjang kenyamanan } \\
\text { pengunjung. Ketiga aspek tersebut antara lain keamanan, } \\
\text { kebersihan, dan ketersediaan tempat duduk. Pada aspek } \\
\text { keamanan, RTH publik aktif diutamakan untuk memiliki } \\
\text { petugas keamanan, sehingga pengunjung dapat merasa aman } \\
\text { saat berkunjung ke RTH publik aktif. Pada aspek kebersihan, } \\
\text { RTH publik aktif juga perlu untuk menyediakan fasilitas } \\
\text { berupa tempat sampah guna menjaga kebersihan dan } \\
\text { memfasilitasi pengunjung untuk turut menjaga kebersihan RTH } \\
\text { publik aktif. Kemudian untuk aspek ketersediaan tempat } \\
\text { duduk, RTH publik aktif diutamakan untuk menyediakan } \\
\text { tempat duduk di dekat ruang bermain anak, sehingga } \\
\text { pengunjung dapat menemani anak mereka bermain sembari } \\
\text { bersantai. Tempat duduk tersebut lebih baik memiliki bahan } \\
\text { dasar kayu jati karena bahan tersebut lebih nyaman untuk } \\
\text { digunakan sebagai tempat duduk. }\end{array}$ \\
\hline $\begin{array}{ll}\text { Akses } & \text { dan } \\
\text { Jaringan } & \end{array}$ & $\begin{array}{l}\text { Lokasi RTH publik aktif di Kecamatan Kepanjen } \\
\text { masih ada yang belum dilewati oleh moda } \\
\text { transportasi publik, sehingga sulit untuk diakses } \\
\text { oleh masyarakat. Hal ini menyebabkan RTH publik } \\
\text { aktif tersebut sepi pengunjung. }\end{array}$ & $\begin{array}{l}\text { Penyediaan RTH publik aktif diutamakan berada di lokasi yang } \\
\text { memiliki aksesibilitas tinggi, yaitu lokasi yang dilewati oleh } \\
\text { berbagai moda transportasi. Selain itu, penyediaan jalur pejalan } \\
\text { kaki menuju RTH publik aktif juga merupakan fasilitas penting } \\
\text { yang perlu untuk disediakan pada sebuah RTH publik aktif } \\
\text { baru. }\end{array}$ \\
\hline Keramahan & $\begin{array}{l}\text { Masih belum ada kelompok khusus pengelola RTH } \\
\text { publik aktif, sehingga pelaksanaan pengelolaan } \\
\text { seringkali terbengkalai. Hal ini menyebabkan } \\
\text { fasilitas yang disediakan di taman mulai mengalami } \\
\text { kerusakan. Selain itu, tingkat keamanan RTH } \\
\text { publik aktif juga masih cukup rendah karena } \\
\text { terdapat RTH publik aktif yang belum memiliki } \\
\text { pagar pembatas. }\end{array}$ & $\begin{array}{l}\text { RTH publik aktif diutamakan untuk memiliki kelompok } \\
\text { pengelola taman guna merawat taman, sehingga kebersihan } \\
\text { RTH publik aktif dapat tetap terjaga. Selain itu, penyediaan } \\
\text { pagar pada RTH publik aktif juga perlu untuk dilakukan. Hal } \\
\text { ini mengingat bahwa pengunjung RTH publik aktif sebagian } \\
\text { besar adalah pengunjung dengan usia anak-anak guna } \\
\text { meningkatkan keamanan RTH publik aktif. }\end{array}$ \\
\hline
\end{tabular}




\section{KESIMPULAN}

Berdasarkan uraian pembahasan mengenai rekomendasi penyediaan $\mathrm{RTH}$ publik aktif di Kecamatan Kepanjen Kabupaten Malang, maka kesimpulan dari penelitian ini, yaitu Kecamatan Kepanjen memiliki lima RTH publik aktif dengan total luas 3,00 ha. RTH publik aktif tersebut berada di Desa Ngadilangkung, Kelurahan Kepanjen, dan Desa Kedungpedaringan. Meskipun Kecamatan Kepanjen telah menyediakan RTH publik aktif, tetapi tidak seluruh desa/kelurahan di kecamatan ini dapat memenuhi persentase minimal penyediaan RTH publik aktif. Berdasarkan analisis kebutuhan RTH publik aktif, Kecamatan Kepanjen hanya memiliki dua desa yang telah memenuhi persentase tersebut, yaitu Desa Ngadilangkung dan Desa Kedungpedaringan.

Penentuan faktor prioritas penyediaan RTH publik aktif di Kecamatan Kepanjen dilakukan dengan mempertimbangkan 10 faktor, yaitu luas, kemiringan lereng, penggunaan lahan di sekitar lokasi, kepadatan penduduk, aksesibilitas lahan, jarak terhadap pusat kota, penggunaan dan aktivitas, kenyamanan, akses dan jaringan, dan keramahan. Analisis AHP menunjukkan bahwa kenyamanan merupakan faktor yang paling berpengaruh dalam penentuan lokasi penyediaan RTH publik aktif di Kecamatan Kepanjen. Masyarakat Kecamatan Kepanjen juga berpendapat bahwa kenyamanan merupakan faktor utama dalam penyediaan RTH publik aktif. Maka, penyediaan RTH publik aktif diutamakan untuk memenuhi faktor tersebut.

Penyediaan RTH publik aktif harus mempertimbangkan tiga aspek yang menunjang kenyamanan pengunjung. Ketiga aspek tersebut antara lain keamanan, kebersihan, dan ketersediaan tempat duduk. Pada aspek keamanan, RTH publik aktif diutamakan untuk memiliki petugas keamanan, sehingga pengunjung dapat merasa aman saat berkunjung ke RTH publik aktif. Pada aspek kebersihan, RTH publik aktif juga perlu untuk menyediakan fasilitas berupa tempat sampah guna menjaga kebersihan dan memfasilitasi pengunjung untuk turut menjaga kebersihan RTH publik aktif. Kemudian untuk aspek ketersediaan tempat duduk, RTH publik aktif diutamakan untuk menyediakan tempat duduk di dekat ruang bermain anak, sehingga pengunjung dapat menemani anak mereka bermain sembari bersantai. Tempat duduk tersebut lebih baik memiliki bahan dasar kayu jati karena bahan tersebut lebih nyaman untuk digunakan sebagai tempat duduk

\section{UCAPAN TERIMA KASIH}

Penulisan jurnal berjudul Rekomendasi Penyediaan RTH Publik Aktif di Kecamatan Kepanjen Berdasarkan Persepsi Masyarakat telah mendapatkan banyak bantuan dari berbagai pihak. Penulis ingin menyampaikan terima kasih kepada keluarga serta sahabat yang selalu memberikan dukungan berupa doa, motivasi, kasih sayang dalam bentuk materil maupun non materil kepada penulis, sehingga dapat menyelesaikan penelitian ini dengan baik. Semoga penelitian ini dapat menjadi referensi dalam perencanaan RTH publik aktif serta dapat menjadi rujukan untuk penelitian sejenis lainnya.

\section{DAFTAR PUSTAKA}

Kementerian Pekerjaan Umum. (2008). Peraturan Menteri Pekerjaan Umum Nomor 5 Tahun 2008 tentang Pedoman Penyediaan dan Pemanfaatan Ruang Terbuka Hijau di Kawasan Perkotaan. Jakarta: Kementerian Pekerjaan Umum.

Kusuma, B. N., Annas, R. D., Putri, A. D., \& Septianto, E. (2014). Telaah Penerapan Kriteria Sustainable Site pada Perumahan Ditinjau dari Aspek Ruang Terbuka Hijau. Jurnal Reka Karsa, 1, $1-12$.

Nasution, A. D. \& Zahrah, W. (2014). Community Perception on Public Open Space and Quality of Life in Medan, Indonesia. Procedia-Social and Behavioral Science, 153, 585-594.

Nugradi, D. N. A. (2009). Identifikasi Ruang Terbuka Hijau Kota Semarang. Jurnal Teknik Sipil \& Perencanaan, 1, 61-70.

Samsudi. (2010). Ruang Terbuka Hijau Kebutuhan Tata Ruang Perkotaan Kota Surakarta. Journal of Rural and Development, 1, 11-19.

Santoso, B., Hidayah, R., \& Sumardjito. (2012). Pola Pemanfaatan Ruang Terbuka Hijau pada Kawasan Perkampungan Plemburan Tegal, Ngaglik Sleman. INERSIA, 8, 1-14.

Sasongko, W., Kurniawati, R. P., \& Siregar, J. P. (2017). The Development Concept of Taman Aloon-aloon Tulungagung based on Visual Accessbility, Diversity of Actovotoes and Perception of Users. IOP Conf. Series: Earth and Environmental Science, 70, $1-10$. 
Setyani, W., Sitorus, S. R. P., \& Panuju, D. R. (2017). Analisis Ruang Terbuka Hijau dan Kecukupannya di Kota Depok. Buletin Tanah dan Lahan, 1, 121-127.

Suhasman, Agussalim, \& Yusuf. (2017). Analisis Persepsi Masyarakat terhadap Taman di Kota Makassar. Jurnal Inovasi dan Pelayanan Publik Makassar, 1, 1-10.

Sumarauw, A. N. (2016). Analisis Kebutuhan Ruang Terbuka Hijau Publik di Kota
Bitung. Jurnal Berkala Ilmiah Efisiensi, 16, 952-961.

Suryadi, K. \& Ramdhani, A. (1998). Sistem Pendukung Keputusan Suatu Wacana Struktural Idealisasi dan Implementasi Konsep Pengambilan Keputusan. Bandung: Remaja Rosdakarya Offset. 